\title{
Deep corneal stromal opacities associated with long term contact lens wear
}

\author{
D Pimenides, C F Steele, C N J McGhee, I G Bryce
}

\begin{abstract}
Background-One male and three female long term contact lens wearers (mean age 30.3 years; range 26-33) demonstrated unusual deep corneal stromal opacities which were predominantly just anterior to Descemet's membrane. None had any history of corneal dystrophy. These opacities were more common centrally, but were also identified in the corneal periphery.

Methods-All patients underwent routine ophthalmic examinations and, where appropriate, slit-lamp photography and specular microscopy.

Results-Mean lens wear in years and hours per day was $14 \cdot 3$ (range 10-17) and $14 \cdot 3$ (range 12-16) respectively. Specular microscopy disclosed cell densities within normal limits (mean $3041 \cdot 5$ cells per $\mathrm{mm}^{2}$ ) and coefficient of variation of mean cell area; $\mathrm{COV}=0 \cdot 31$. Refractive errors ranged from $-12 \cdot 25 \mathrm{D}$ to $+6 \cdot 25$ best vision sphere and all four subjects attained at least 6/9 Snellen visual acuity. The subjects' contact lens wearing history included low water content hydroxymethylmethacrylate (HEMA) contact lenses and high water content HEMA contact lenses. Stromal opacity density was observed to diminish over a period of months on cessation of contact lens wear in two cases.
\end{abstract}

Conclusion-The possible causes of these rarely reported opacities are discussed. (Br F Ophthalmol 1996; 80: 21-24)

The most frequent complications of contact lens wear are a result of corneal hypoxia or anoxia. ${ }^{1}$ These may be caused by extended wear or prolonged daily wear of lenses made from materials with zero or poor oxygen transmissibility (Dk/L) - for example, polymethylmethacrylate (PMMA) and low to mid water content hydroxymethylmethacrylate (HEMA) lenses. The effects of long term

Corneal Diseases and Excimer Laser Unit, Sunderland Eye Infirmary D Pimenides C F Steele C N J McGhee I G Bryce

Correspondence to: Professor C N J McGhee, Corneal Diseases and Excimer Laser Unit, Sunderland Eye Infirmary, Queen Alexandra Road, Sunderland SR2 9HP.

Accepted for publication 20 September 1995

Table 1 Summary of subjects' contact lens history contact lens wear, including extended wear, are now generally well documented. ${ }^{12}$ The stroma is subject to contact lens induced changes such as hypoxia, ${ }^{3}$ increased osmolality, acidic shift in $\mathrm{pH}$, and mechanical pressure. ${ }^{4}$ These stromal changes may result in oedema, distortion, and thinning. ${ }^{2}$ Deep stromal opacities have rarely been reported in the literature associated with contact lens wear. $^{5-9}$

On examination, four long term contact lens wearers (two of whom were prospective photorefractive keratectomy (PRK) patients) demonstrated unusual deep corneal stromal opacities just anterior to Descemet's membrane. These opacities were most common centrally but were also identified in the corneal periphery. The possible causes of these stromal opacities are discussed.

\section{Patients and methods}

Between June 1993 and May 1994, 324 patients were assessed in the Corneal Diseases and Excimer Laser Unit of whom many were current contact lens wearers. Four patients demonstrated unusual deep stromal opacities just anterior to Descemet's membrane. All patients underwent routine ophthalmic examinations and, where appropriate, slit-lamp photography (using a Topcon SL7 photo slitlamp) and specular microscopy (Konan Research Institute Inc, Japan) were performed. The best of three endothelial photographs from each eye was chosen and the coefficient of variation of mean cell area was scored subjectively. A standard questionnaire was used to ascertain individual contact lens wearing history.

\section{Results}

A description of the data is presented in Table 1. Four patients, who were all long term soft contact lens wearers (mean age 30.3 (range 20-33) years), demonstrated bilateral deep corneal stromal opacities just anterior

\begin{tabular}{|c|c|c|c|c|c|}
\hline & Case 1 & Case 2 & Case 3 & Case 4 & Mean \\
\hline $\begin{array}{l}\text { Age (years) } \\
\text { Soft contact lens type }\end{array}$ & $\begin{array}{l}33 \\
\text { Hydron } \mathrm{Z}^{2} \\
\quad\left(38 \% \mathrm{H}_{2} \mathrm{O}\right)\end{array}$ & $\begin{array}{l}32 \\
\text { Hydron } \mathrm{Z6} \\
\quad\left(38 \% \mathrm{H}_{2} \mathrm{O}\right)\end{array}$ & $\begin{array}{l}26 \\
\text { Barnes Hind } \\
\quad \text { Permaflex } 74\end{array}$ & $\begin{array}{l}46 \\
\text { Barnes Hind } \\
\quad \text { Permaflex } 74\end{array}$ & $34 \cdot 25$ \\
\hline $\begin{array}{l}\text { No of years of contact lens wear } \\
\text { No of hours of contact lens }\end{array}$ & 10 & 17 & 16 & 16 & $14 \cdot 75$ \\
\hline $\begin{array}{l}\text { wear per day } \\
\text { Lens care system } \\
\text { Contact lens solution } \\
\text { preservative }\end{array}$ & $\begin{array}{l}12 \\
\text { Boots own } \\
\text { brand } \\
0.0025 \% \text { thiomersal, } \\
0.0025 \% \text { chlorhexidine } \\
\text { gluconate }\end{array}$ & $\begin{array}{l}15 \\
\text { Ciba Vision } \\
10 / 10\left(\mathrm{H}_{2} \mathrm{O}_{2}\right) \\
\mathrm{Nil}\end{array}$ & $\begin{array}{l}15 \\
\text { Ciba Vision } \\
10 / 10\left(\mathrm{H}_{2} \mathrm{O}_{2}\right) \\
\text { Nil }\end{array}$ & $\begin{array}{l}16(10) \\
\text { Allergan } \\
\text { Hydrocare } \\
0.002 \% \text { thiomersal, } \\
0 \cdot 03 \% \text { alkyl } \\
\text { triethanol } \\
\text { ammonium }\end{array}$ & 14.5 \\
\hline
\end{tabular}


Table 2 Refractive data and results of specular microscopy

\begin{tabular}{|c|c|c|c|c|}
\hline Patient & Refraction & $\begin{array}{l}\text { Cell density } \\
\text { per } \mathrm{mm}^{2}\end{array}$ & $\begin{array}{l}\text { Cell size } \\
\times 10^{-4}\end{array}$ & $\begin{array}{l}\text { Coefficient of variation } \\
\text { of mean cell area (COV) }\end{array}$ \\
\hline $\begin{array}{c}\text { Case 1: } \\
\text { Right } \\
\text { Left }\end{array}$ & $\begin{array}{l}-4.00 /-2.00 \times 170 \\
-6.00 /-1.50 \times 85\end{array}$ & $\begin{array}{l}2227 \\
\text { Poor }\end{array}$ & $\begin{array}{l}4 \cdot 49 \\
\text { Unobtainable }\end{array}$ & $0 \cdot 31$ \\
\hline $\begin{array}{c}\text { Case 2: } \\
\text { Right } \\
\text { Left }\end{array}$ & $\begin{array}{l}+6.50 /-0.75 \times 20 \\
+6.50 /-0.75 \times 170\end{array}$ & $\begin{array}{l}2577 \\
2707\end{array}$ & $\begin{array}{l}3 \cdot 87 \\
3.69\end{array}$ & $\begin{array}{l}0.43 \\
0.46\end{array}$ \\
\hline $\begin{array}{c}\text { Case 3: } \\
\text { Right } \\
\text { Left }\end{array}$ & $\begin{array}{l}-11 \cdot 25 /-0.25 \times 140 \\
-12 \cdot 00 /-0.5 \times 180\end{array}$ & $\begin{array}{l}3880 \\
4424\end{array}$ & $\begin{array}{l}2 \cdot 56 \\
2 \cdot 26\end{array}$ & $\begin{array}{l}0 \cdot 19 \\
0 \cdot 23\end{array}$ \\
\hline $\begin{array}{c}\text { Case 4: } \\
\text { Right } \\
\text { Left }\end{array}$ & $\begin{array}{l}+5.25 /-0.50 \times 90 \\
+6.50 /-1.00 \times 70\end{array}$ & $\begin{array}{l}2446 \\
3030\end{array}$ & $\begin{array}{l}4 \cdot 09 \\
3 \cdot 31\end{array}$ & $\begin{array}{l}0 \cdot 33 \\
0 \cdot 22\end{array}$ \\
\hline $\begin{array}{c}\text { Mean: } \\
\text { Right } \\
\text { Left }\end{array}$ & & $\begin{array}{l}2782 \\
3387\end{array}$ & $\begin{array}{l}3 \cdot 75 \\
3.08\end{array}$ & $\begin{array}{l}0.31 \\
0.30\end{array}$ \\
\hline
\end{tabular}

to Descemet's membrane. These varied in severity and were more common centrally but were also observed in the corneal periphery. None of the patients reported symptoms associated with these findings, and the ocular adnexae were otherwise unremarkable. Mean lens wear was 14.3 (range 10-17) years and $14 \cdot 3$ (range 12-16) hours per day (Table 1 ). There was no history of corneal dystrophy in any patient, all were in good health and receiving no topical or systemic medication. Two patients were using, and had always used, preserved contact lens care solutions and the other two were using preservative free lens care systems (Table 1).

Table 2 summarises the refractive data with a best corrected Snellen visual acuity of $6 / 6$ in any patient. Specular microscopy revealed a right mean cell density of 2782 per $\mathrm{mm}^{2}$ and left of 3387 per $\mathrm{mm}^{2}$ with coefficient of variation of mean cell areas (COV) of right 0.31 and left $0 \cdot 30$. The mean follow up was 14 months and during this period the stromal opacities described in two cases diminished on cessation of contact lens wear, with the other two remaining unchanged. A summary of the relevant observations and salient details with regard to each patient's contact lens wearing history are given in the following case reports.

CASE 1

In case 1, deep whitish grey fleck-like opacities were observed most frequently in the central posterior one third stroma close to Descemet's membrane. They were of approximately equal density in each eye. Gonioscopy was normal in both eyes. Following cessation of contact lens wear after PRK, these stromal opacities became much less marked and faded in intensity.

CASE 2

Multiple relatively dense, greyish white, opacities were also noted in the posterior one third stroma in case 2 . These were only located within the central $4 \mathrm{~mm}$, just anterior to Descemet's membrane and were irregular in outline (Figs 1 and 2). No opacities were detected in the corneal periphery. The opacities observed were the largest and most marked in this series.

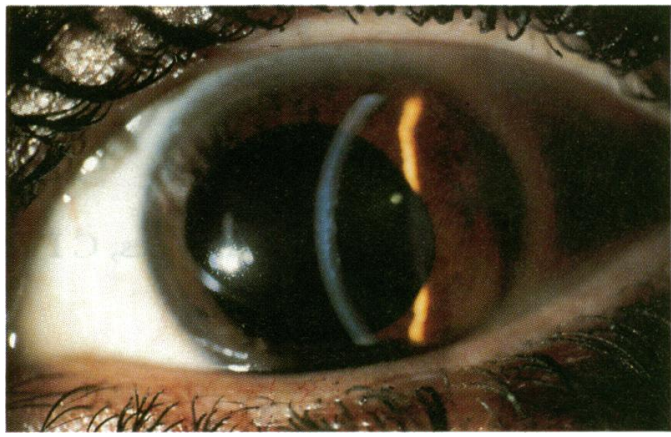

Figure 1 Case 2. Multiple dense, central, greyish white opacities in posterior one third stroma ( $\times 6$ magnification).

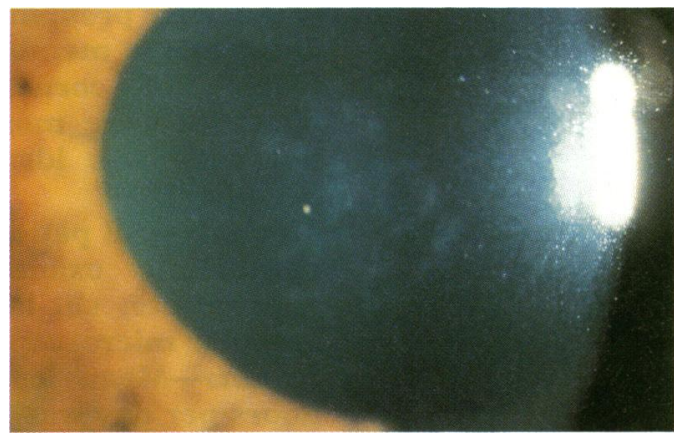

Figure 2 Case 2. Stromal opacities ( $\times 9$ magnification).

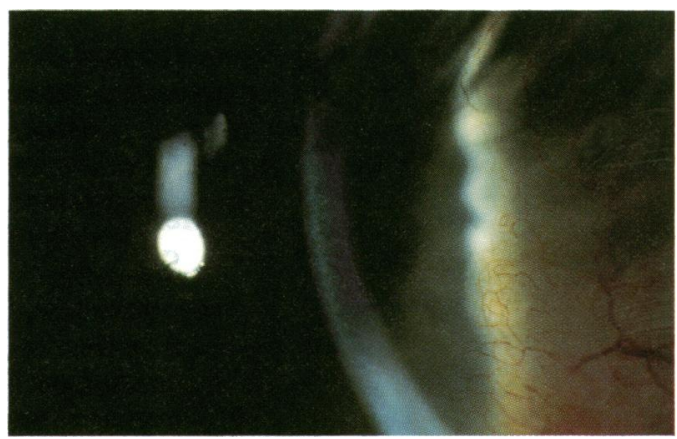

Figure 3 Case 3. Multiple very fine whitish, fleck-like opacities scattered throughout the anterior and mid stroma ( 6 magnification).

CASE 3

In case 3, multiple very fine, whitish, fleck-like opacities were observed predominantly in the posterior stroma, although flecks were also visible in the anterior and mid stroma, which were more prominent in the right eye (Fig 3). They appeared evenly distributed in both the central cornea and in the corneal periphery, just anterior to Descemet's membrane. The fleck opacities diminished in intensity with cessation of lens wear following PRK.

CASE 4

Diffuse, multiple, brownish white, punctate opacities were observed in the posterior one third stroma in case 4. Although these opacities were present in the corneal periphery they were more marked centrally. In the left central cornea the density of these opacities gave a cloudy appearance to the posterior stroma, just anterior to Descemet's membrane. This area was approximately $2.5 \mathrm{~mm}$ in diameter, just inferior to the corneal centre. A slightly less 
marked appearance was observed in the right eye. Fine peripheral vascularisation of the corneas was also noted with vessels extending approximately $2 \mathrm{~mm}$ from the limbus and gonioscopy was normal.

\section{Discussion}

Four patients, who were all long term soft contact lens wearers (Table 1), were observed to have deep, flecked, corneal stromal opacities, just anterior to Descemet's membrane more predominantly in the central than the peripheral cornea. It has been suggested that such deep stromal opacities can take an asymptomatic course. ${ }^{5}$ Others have associated symptoms such as reduced visual acuity, photophobia, and ocular discomfort with the development of the opacities they described. ${ }^{6}$ Possible causes of this clinical presentation include corneal hypersensitivity to contact lens solutions ${ }^{8}$ and materials, ${ }^{10}$ hereditary corneal dystrophy, ${ }^{11}$ or the effects of corneal hypoxia. ${ }^{2} 3$ Other aetiologies might include viral, chlamydial, herpetic, or staphylococcal infections. ${ }^{1}$

Thiomersal and chlorhexidine preservatives are reported to cause a high incidence of patient hypersensitivity or toxic reactions ${ }^{12-15}$ which could be responsible for the development of anterior corneal opacities, but it is less likely that thiomersal could cause deep stromal changes. ${ }^{16}$ Only two of the patients presented were currently using lens care systems containing thiomersal preservative. The other two patients were using Ciba Vision's preservative free hydrogen peroxide 10/10 lens care system, which was first available in the mid 1980s. All these patients had worn lenses for at least 10 years. Therefore, it is possible that these patients used chemical disinfection lens care systems, before $10 / 10$, which contained thiomersal or chlorhexidine. The likelihood of any reaction causing continued deep stromal changes over such a time scale seems remote.

Although plastic in contact lenses has been suggested as an antigenic stimulus for giant papillary conjunctivitis (GPC), ${ }^{17}$ it is noteworthy that none of the presented patients showed any signs or symptoms of GPC ${ }^{18}$ and therefore a corneal hypersensitivity reaction to contact lens materials as a possible cause of these corneal opacities also seems unlikely.

Pre-Descemet's dystrophies manifest in the early $30 \mathrm{~s}^{11}$ and all are more common in females and may or may not be inherited. ${ }^{19}$ Three of these patients were female, two in their early $30 \mathrm{~s}$. The clinical features presented, with the exclusion of opacity resolution, might, therefore, have been attributed initially to a pre-Descemet's dystrophy, despite the absence of any family history of corneal dystrophy.

Most workers conclude that these lesions have no effect on visual acuity (VA). However, it may be significant that three of our patients could not attain a visual acuity greater than $6 / 6$. The distribution of stromal opacities in our patients was of particular interest. The eye with low myopia (case 1) and the two hyper- metropic eyes (cases 2 and 4) each had more centrally located opacities, whereas the case of high myopia (case 3) had more diffuse opacities. This could be related to the relative thickness of a soft contact lens at its centre and periphery with regard to a high minus lens being thickest at its periphery and a high plus lens being thickest at its centre. These factors might be of particular importance if these lesions are associated with corneal hypoxic stress induced by soft HEMA contact lenses with poor (less than $34 \times 19^{-9}$ fatt units) oxygen transmissibility ( $\mathrm{Dk} / \mathrm{L})$, where $\mathrm{D}$ is the diffusion coefficient of the material, $k$ is the solubility coefficient of the material, and $\mathrm{L}$ is the thickness. ${ }^{2}$ The amount of oxygen delivered to the cornea by tear pumping with soft contact lenses is relatively small, therefore the cornea is dependent on oxygen diffusion through the lens material. ${ }^{20}$ An important consideration is the moderately high ametropia in all of the presented cases, since even in the case of high water content soft contact lenses, which are relatively thick, the $\mathrm{Dk} / \mathrm{L}$ might still be too low to prevent corneal hypoxic changes, even during daily contact lens wear. ${ }^{21}$ Deep stromal opacities associated with contact lens wear have been reported to diminish in opacity density with cessation of contact lens wear, or by changing patients to gas permeable materials, with their much higher $\mathrm{Dk} / \mathrm{L}$ values. $^{5-7}$ Additionally, unilateral opacities have always corresponded to the contact lens wearing eye. ${ }^{5}$ Most other reports in the literature suggest that the opacities seen in association with contact lens wear diminish very slowly, possibly taking years. ${ }^{78}$ In these case presentations the stromal opacities appeared to diminish in two patients on cessation of contact lens wear.

The effects of barometric decompression on contact lens wearers has been demonstrated, where stromal opacities were observed to develop after a 4 hour period under this induced state of hypoxia. ${ }^{22}$ There is a statistically significant increased endothelial permeability in long term contact lens wearers with deep stromal opacities compared with those contact lens wearers without stromal opacities. ${ }^{23}$ Morphological changes in the corneal endothelium indicate hypoxic stress to the endothelium which could ultimately lead to cell loss. ${ }^{5}$ The role of the endothelium in producing these deep stromal opacities may be significant and this theory has the most support with other workers; however, in our cases specular microscopy actually revealed cell densities within normal limits. A small but significant endothelial cell loss has been reported in long term hard lens wearers which increased with length of lens wear. ${ }^{24}$ According to Yee et $a l^{25}$ the ratio of the standard deviation of cell size divided by the mean cell size that is, the coefficient of variation of mean cell area (COV) varies from 0.27 (SD 0.017 ) to 0.29 (SD 0.008) for the age range 20 to 60 years. In the cases presented the COV was actually slightly higher at $0 \cdot 31$, and although this agrees with the COV for a normal young population given by Holden et $\mathrm{al}^{3}$ it was noted 
that the mean COV was abnormally high in patient 2 (mean $\mathrm{COV}=0 \cdot 445$ ).

\section{Conclusion}

In conclusion, we believe that long term soft contact lens wear with low to middle oxygen transmissibility $(\mathrm{Dk} / \mathrm{L})$ contact lens materials may induce a stromal keratopathy producing fleck-like opacities in the posterior stroma, possibly as a form of endothelial dysfunction associated with corneal exhaustion syndrome. The stromal opacities observed in these cases appear to be similar to those rarely described by other workers in the international literature. ${ }^{5-8}$

1 Tomlinson A. Complications of contact lens wear. 1st ed. St Louis: Mosby Year Book, 1992.

Holden BA. The Glenn A Fry lecture 1988. The ocula response to contact lens wear. Optom Vis Sci 1989; 66: 717-33.

3 Holden BA, Sweeney DF, Vannas A, Nilsson KT, Efron N Effects of long term extended contact lens wear on the human cornea. Invest Ophthalmol Vis Sci 1985; 26: 1489-501.

4 Bonanno J, Polse K. Corneal acidosis during contact lens wear: effects of hypoxia and carbon dioxide. Invest wear: effects of hypoxia and carbon

5 Remeijer L, Van Rij G, Beekhuis H, Polak B, Van Nes J. Deep corneal stromal opacities in long term contact len wear. Ophthalmology 1990; 97: 281-5.

6 Brooks MV, Grant G, Westmore R, Robertson IF. Deep corneal stromal opacities with contact lenses. Aust NZ Ophthalmol 1986; 14: 243-9.

7 Duba I, Bigar F. Hornhautveranderungen bei weichen kontaklinsentragen. Klin Monatsbl Augenheilkd 1986; 188: 363-4.

8 Kilp H, Konen W, Zschausch B, Lemmen K. Tiefe und hartnackige hornautparencymschaden nach kontaklinsen und ihr verlauf. Fortschr Ophthalmol 1982; 79: 116-7.

9 Pinkers A, Eggink F, Aandererk AL, Van T Pad. A contact lens induced pseudo-dystrophy of the cornea. Doc Ophthalmol 1987; 65: 433-7.

10 Reetschel RC, Wilson LA. Ocular inflammation in patients using soft contact lenses. Arch Dermatol 1987; 118: 147-9.

11 Affra RC. Grayson's diseases of the cornea. 3rd ed. St Louis: Mosby Year Book, 1991.

12 Mondino BJ, Groden LR. Conjunctival hyperaemia and corneal infiltrates with chemically disinfected soft contact lenses. Arch Ophthalmol 1980; 98: 1767-70.

13 Wilson LA, McNatt J, Reitschel R. Delayed hypersensitivity to thiomerosal in soft contact lens wearers. Ophthalmology 1981; 88: 804-9.

14 Green K, Livingston V, Bowman K, Hull DS. Chlorhexidine effects on corneal epithelium and endothelium. Arch Ophthalmol 1980; 98: 1273-8.

15 Wilson-Holt NJ, Dart JK. Thiomersal keratoconjunctivitis; frequency, clinical spectrum and diagnosis. Eye 1989; 3: $581-7$.

16 Van Horn DL, Edelhauser HF, Prodanovich G, Eiserman R, Pederson HF. Effect of the ophthalmic preservative
thimerosal on rabbit and human corneal endothelium. Invest Ophthalmol Vis Sci 1977; 16: 273-80.

17 Reynolds RMS. GPC: a mechanical theory. Aust 7 Optom 1978; 61: 320-3.

18 Alansmith MR, Korb DR, Greiner JV, Henriquez AS, Simon MA, Sinnemore VM. GPC in contact lens wearers. Am $\mathcal{f}$ Ophthalmol 1977; 83: 607-708.

19 Grayson M, Willbrandt H. Pre-Decscemet dystrophy. Am f Ophthalmol 1967; 64: 276-82.

20 Polse KA. Tear flow under Hydrogel contact lenses. Invest Ophthalmol Vis Sci 1979; 18: 409-13.

21 Holden BA. Perspectives on the future of contact lens wear: summary. Cornea 1990; 9 (suppl 1): S69-71.

22 Castron J, Tuovinen E, Lansimies E, Stenberg T, Aho J, Nedrum K. Contact lenses in hypoxia. Acta Ophthalmol (Copenh) 1985; 63: 439-42.

23 Gobbels M, Wahning A, Spitznas M. Endothelial function in contact lens induced deep corneal opacities. Fortschr Ophthalmol 1989; 86: 448-50.

24 Caldwell DR, Kastl PR, Dabezies OH, Miller KR, Hawk TJ. The effect of long term hard wear on corneal endothelium. Contact Intraocul Lens Med f 1982; 8: 87-91.

25 Yee RW, Matsuda M, Schultz RO, Edelhauser HF. Changes in the normal corneal endothelial cellular pattern as a function of age. Curr Eye Res 1985; 4: 671-8. 